\title{
Laboratory-scale investigation of the removal of hydrogen sulfide from biogas and air using industrial waste-based sorbents
}

\author{
Olumide Wesley Awe ${ }^{\mathrm{a}, \mathrm{b}, *}$, Doan Pham Minh ${ }^{\mathrm{b}, * *}$, Nathalie Lyczko $^{\mathrm{b}}$, Ange Nzihou $^{\mathrm{b}}$, \\ Yaqian Zhao ${ }^{\mathrm{a}}$

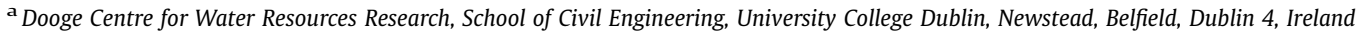 \\ ' Universite' de Toulouse, Mines Albi, CNRS UMR 5302, Centre RAPSODEE, Campus Jarlard, Albi, F-81013 cedex 09, France
}

A B S T R A C T

Keywords:

Biogas

Activated carbon

Calcium carbonate waste

Purification

Adsorption

$\mathrm{H}_{2} \mathrm{~S}$ removal
Biogas is a valuable renewable energy that can be used as a fuel or as raw material for the production of hydrogen, synthesis gas and chemicals. Apart from its main constituent of $\mathrm{CH}_{4}$ and $\mathrm{CO}_{2}$, it also contained various undesirable contaminants. The removal of these contaminants such as $\mathrm{H}_{2} \mathrm{~S}$ will significantly improve the quality of the biogas for further use. This work involved the valorization of calcium carbonate $\left(\mathrm{CaCO}_{3}\right.$ )-based solid wastes for the removal of $\mathrm{H}_{2} \mathrm{~S}$ from the biogas stream. The solid wastes were analyzed by different physicochemical methods $\mathrm{CaCO}_{3}$ was found as the main component of both solid wastes, while trace amounts of other elements such as $\mathrm{Mg}$, $\mathrm{Al}$, etc. were also present. The solid wastes were dispersed in water and the resulted suspensions were tested for the removal of $\mathrm{H}_{2} \mathrm{~S}$ from the gas phase, using a triphasic gas/liquid/solid glass reactor at room temperature and pressure. A commercial activated carbon $(\mathrm{AC})$ and a pure commercial calcite were also used for comparison purpose. In addition, mixtures of $\mathrm{AC}$ with $\mathrm{CaCO}_{3}$ waste in different ratios were also tested. The influence of the matrix of gas (air or biogas) on the removal of $\mathrm{H}_{2} \mathrm{~S}$ was evaluated. Both solid wastes showed higher performance compared to the pure commercial calcite for $\mathrm{H}_{2} \mathrm{~S}$ removal. The coupling of a $\mathrm{CaCO}_{3}$ waste and $\mathrm{AC}$ allowed improving the sorption performance compared to pure commercial $\mathrm{CaCO}_{3}$ and $\mathrm{AC}$ used alone. The results obtained open a new promising way for the valorization of $\mathrm{CaCO}_{3}$-based wastes for $\mathrm{H}_{2} \mathrm{~S}$ removal from biogas.

\section{Introduction}

Biogas is a renewable energy resource that can be an alternative solution for the world insatiable energy demands and at the same time help in reducing waste and the greenhouse gas (GHG) emissions [1]. It is also regarded as carbon neutral because the carbon in biogas comes from organic matter (feedstocks) that captures this carbon from atmospheric $\mathrm{CO}_{2}$ over relative short timescale [2]. When biogas is produced, waste is converted to energy thereby reducing the refuse mountain (landfill) disposal and providing with energy supplies security without any significant environment impact [1]. The production of biogas also provides an eco-friendly, high-value useable by-product (bio-

\footnotetext{
* Corresponding author at: Dooge Centre for Water Resources Research, School of Civil Engineering, University College Dublin, Newstead, Belfield, Dublin 4, Ireland.

** Corresponding author.

E-mail addresses: wesley.awe@ucdconnect.ie (O.W. Awe), doan.phamminh@mines-albi.fr (D.P. Minh).
}

fertilizer) for soil conditioning and improvement [2]. Thus it is highly regarded as effective method of waste management $[3,4]$.

The chemical composition of biogas largely depends on the origins and the kind of substrates used such as methanation of biomass, organic wastes from sewage sludge, animal farm manure, energy crops, and agro-food industry waste [5]. Different processes currently exist and can be used for the generation of biogas such as anaerobic digestion, anaerobic co-digestion, landfills, commercial composting, and agro-food industry digestion facilities, under both mesophilic $\left(35^{\circ} \mathrm{C}\right)$ and thermophilic $\left(55^{\circ} \mathrm{C}\right)$ conditions [6].

The composition of raw biogas from the anaerobic degradation of sewage sludge, livestock manure, industrial and agro- bio-waste are shown in Table 1 . The lower heating value of biogas ranges from 15 to $30 \mathrm{MJ} / \mathrm{Nm}^{3}$ and is lower than that of natural gas, which is around $36 \mathrm{MJ} / \mathrm{Nm}^{3}[5,6]$.

Hydrogen sulfide along with other $S$ bearing compounds (mercaptans etc.) are the most common contaminants in biogas and their content, which can vary from 100 to $10,000 \mathrm{ppm}$, depends largely on the composition of the organic matter, mostly protein-rich streams. They are also formed in different 
Table 1

Composition and parameters of gases from different origins, impurities and their consequences [5,12,20,43-47].

\begin{tabular}{|c|c|c|c|c|c|c|}
\hline Parameters & Unit & $\begin{array}{l}\text { Landfill } \\
\text { Gas }\end{array}$ & $\begin{array}{l}\text { Biogas from } \\
\text { AD }\end{array}$ & $\begin{array}{l}\text { Dutch } \\
\text { Natural Gas }\end{array}$ & $\begin{array}{l}\text { North Sea } \\
\text { Natural Gas }\end{array}$ & Impact on biogas utilization \\
\hline & $\begin{array}{l}\mathrm{MJ} / \\
\mathrm{Nm}^{3}\end{array}$ & 16 & 23 & 31.6 & 40 & \\
\hline \multirow[t]{2}{*}{$\begin{array}{l}\text { Lower heating } \\
\text { value }\end{array}$} & $\begin{array}{l}\mathrm{KWh} / \\
\mathrm{Nm}^{3}\end{array}$ & 4.4 & 6.5 & 8.8 & 11 & \\
\hline & $\mathrm{MJ} / \mathrm{kg}$ & 12.3 & 20 & 38 & 47 & \\
\hline Density & $\mathrm{Kg} /$ & 1.3 & 1.1 & 0.8 & 0.84 & \\
\hline $\begin{array}{l}\text { Relative } \\
\text { density }\end{array}$ & - & 1.1 & 0.9 & 0.6 & 0.63 & \\
\hline $\begin{array}{l}\text { Wobbe index, } \\
\text { upper }\end{array}$ & $\begin{array}{l}\mathrm{MJ} / \\
\mathrm{Nm}^{3}\end{array}$ & 18 & 27 & 43.7 & 55 & \\
\hline $\begin{array}{l}\text { Methane } \\
\text { number }\end{array}$ & - & $>130$ & $>135$ & - & 73 & \\
\hline Methane $\left(\mathrm{CH}_{4}\right)$ & Vol-\% & $35-65$ & $60-70$ & $80-90$ & $85-92$ & \\
\hline $\begin{array}{l}\text { Heavy } \\
\text { hydrocarbons }\end{array}$ & Vol-\% & 0 & 0 & 9 & 9 & \\
\hline $\begin{array}{l}\text { Water vapour } \\
\left(\mathrm{H}_{2} \mathrm{O}\right)\end{array}$ & Vol\% & $1-5$ & $1-5$ & - & - & $\begin{array}{l}\text { Corrosion in compressors, gas storage tanks and engines due to reaction with } \mathrm{H}_{2} \mathrm{~S} \text {, } \\
\mathrm{NH}_{3}, \mathrm{CO}_{2} \text { to form acids }\end{array}$ \\
\hline Hydrogen & Vol-\% & 0 & 0 & - & 0 & \\
\hline Carbon dioxide & Vol-\% & $15-40$ & $30-40$ & $0.2-1.5$ & $0.2-1.5$ & Decreasing calorific value, anti-knock properties of engines and corrosion \\
\hline Nitrogen, range & Vol-\% & 15 & $0-0.5$ & 14 & $0.3-1.0$ & Decreasing calorific value, anti-knock properties of engines and corrosion \\
\hline Oxygen & Vol-\% & 1 & 0 & - & - & Corrosion, fooling in cavern storage, risk of explosion \\
\hline $\begin{array}{l}\text { Hydrogen } \\
\text { sulfide }\end{array}$ & Ppm & $0-100$ & $0-4000$ & - & $1.1-5.9$ & $\begin{array}{l}\text { Corrosion, catalytic converter poison, emission and health hazards. } \mathrm{SO}_{2}, \mathrm{SO}_{3} \text { are } \\
\text { form }\end{array}$ \\
\hline $\begin{array}{l}\text { Ammonia } \\
\left(\mathrm{NH}_{3}\right)\end{array}$ & Ppm & 5 & 100 & - & 0 & Emission, anti-knock properties of engines and corrosion when dissolved \\
\hline $\begin{array}{l}\text { Total chlorine } \\
\text { as } \mathrm{Cl}^{-}\end{array}$ & $\begin{array}{l}\mathrm{Mg} / \\
\mathrm{Mm}^{3}\end{array}$ & $20-200$ & $0-5$ & - & - & Corrosion in engines \\
\hline
\end{tabular}

anthropogenic processes such as; coal combustion, paper mills, food industries, wastewater treatment plants, animal farms, gasification of biomass or coal for syngas production or petrochemical processing, etc. [7-9]. So it can be used in chemical processes for the production of various products, including synthetic gas (syngas, mixture of $\mathrm{CO}$ and $\mathrm{H}_{2}$ ), hydrogen, methanol and other hydrocarbons [10]. They must be removed before any utilization because they are highly corrosive to the metallic parts of engines, pipes, pumps, compressors, gas storage tanks, valves and reduce the lifespan of process equipment, most especially in the presence of water and trace of oxygen in the biogas. This result in extra costs of infrastructures and maintenance [11,12]. They have also serious environmental concerns due to their oxidation to sulfur dioxide $\left(\mathrm{SO}_{2}\right)$ and sulfuric acid $\left(\mathrm{H}_{2} \mathrm{SO}_{4}\right)$ [2]. The environmental concerns of $\mathrm{H}_{2} \mathrm{~S}$ include acid rain due to high solubility of sulfur-containing compounds in water. This happens when $\mathrm{H}_{2} \mathrm{~S}$ is released in form of gas, it remains in the atmosphere and spread for an average of $18 \mathrm{~h}$, during which time it is oxidized to sulfur dioxide $\left(\mathrm{SO}_{2}\right)$ and sulfuric acid $\left(\mathrm{H}_{2} \mathrm{SO}_{4}\right)$. Also, because it is a colourless and flammable gas that smells like rotten eggs, it can be perceived at low concentration ranging from $0.0005-0.3$ part per million ( $\mathrm{ppm}$ ). However, at high concentration, a person might lose the sense of smell, which poses serious danger to people's health, because of false assumptions that it is no longer present. This can increase their exposure to higher concentration level that may cause serious health effects. At concentration $100-1000 \mathrm{ppm}$, there is loss of smell, serious respiration troubles, ocular irritation, loss of consciousness, with immediate death above $1000 \mathrm{ppm}[2,13]$.

Basically, there are two main utilizations of biogas. It can be either upgraded to reach the energetic density of natural gas or purified for chemical transformation processes. Biogas upgrading consists of the adjustment of $\mathrm{CO}_{2}$ content, to increase the calorific value of the biogas to optimal level. Thus, biomethane is the final product which composes of $\mathrm{CH}_{4}(95-99 \%)$ and $\mathrm{CO}_{2}$ (1-5\%), with little or no trace of $\mathrm{H}_{2} \mathrm{~S}$ and other compounds [14]. Biogas purification involves the removal of harmful, toxic, and/or unnecessary compounds such as $\mathrm{H}_{2} \mathrm{~S}, \mathrm{~N}_{2}, \mathrm{O}_{2}, \mathrm{Si}, \mathrm{H}$, VOCs, CO, and $\mathrm{NH}_{3}$. Purified biogas contains mostly $\mathrm{CH}_{4}$ and $\mathrm{CO}_{2}$ with low content of contaminants.

In recent years, several technologies have been developed for syngas cleaning, and their main differences are related to the nature of the operation. Catalytic processes involve the oxidation of $\mathrm{H}_{2} \mathrm{~S}$ over solid catalysts, in order to convert it to molecular sulfur, sulfide, thiosulfate and sulfate [9,15]. Biological processes utilize bacteria such as Thiobacillus and Sulfolobus family, for the oxidation of $\mathrm{H}_{2} \mathrm{~S}$ into elemental sulfur or sulfate [16]. This process requires strict operational conditions to control pressure, temperature, input composition bacterial and energy sources, etc. [17]. Other advanced methods had been investigated and developed such as hydrate formation for $\mathrm{H}_{2} \mathrm{~S}$ separation [18-22]. These technologies are found to be efficient for biogas purification and upgrading. However, they still need to be improved for enhancing performance and reducing operational cost [23]. In this context, there is increasing interest to develop new low cost and efficient materials as sorbent for biogas treatment. This has led to investigation of industrial and agricultural wastes and sewage sludge [24] as alternative sorbents for $\mathrm{H}_{2} \mathrm{~S}$ removal from biogas.

Biological desulphurization and biofiltration of $\mathrm{H}_{2} \mathrm{~S}$ technology mentioned above employed specialized microorganisms to reduce the level of $\mathrm{H}_{2} \mathrm{~S}$ in biogas by converting it to elemental sulfur and some sulphates, similar to the technique of addition of air or oxygen into the digestion tank. The technique is on the basis of lithautotrophic bacteria to use $\mathrm{H}_{2} \mathrm{~S}$ as electron donor and $\mathrm{CO}_{2}$ as carbon source, and also for the development of end-of-pipe solutions for biogas upgrading [25,26]. About $4-6 \%$ of air/oxygen was used as electron acceptor and provided the energy needed for lithotrophic growth in order to oxidize $\mathrm{H}_{2} \mathrm{~S}$ [25]. Hydrate formation process was firstly proposed by Yoon and Lee [27] who 
investigated clathrate phase equilibrium for the water-phenolcarbon dioxide system based on the equilibrium partition of the components between gaseous phase and the hydrate phase. Kang et el. [18] used this principle to work on gas hydrate process for the recovery of $\mathrm{CO}_{2}$ from flue gas. According to Tajima et al. [21], the basic mechanism of the separation process is a selective partition of the target component between the hydrate phase and the gaseous phase. Generally, the hydrate phase is stable under high pressure-low temperature conditions. This has attracted other researchers to look at the possibility of employing this technology to reduce $\mathrm{CO}_{2}, \mathrm{H}_{2} \mathrm{~S}$, and other contaminants from biogas and syngas streams.

This paper investigated the reactivity of calcium carbonate $\left(\mathrm{CaCO}_{3}\right.$ )-based solid wastes (CCWs) for the removal of $\mathrm{H}_{2} \mathrm{~S}$ from simulated biogas matrix $\left(\mathrm{H}_{2} \mathrm{~S}\right.$ in biogas) and synthetic waste gas matrix $\left(\mathrm{H}_{2} \mathrm{~S}\right.$ in air), using triphasic gas/liquid/solid process at room temperature and atmospheric pressure. The main objective of the study was the development of new and low cost sorbents for the treatment of $\mathrm{H}_{2} \mathrm{~S}$ in the gas phase. The solid wastes, called thereafter CCW-D (Calcium Carbonate -based solid Waste, sample D) and CCW-S (Calcium Carbonate -based solid Waste, sample S), were taken from two different industrial sites of the production of sodium carbonate and sodium bicarbonate, and were analyzed by different physicochemical methods. Up-to-date, these wastes are not valorized for any useful material. In addition, they contain trace amounts of various metals such as $\mathrm{Mg}, \mathrm{Al}, \mathrm{Fe}, \mathrm{Si}, \mathrm{Cl}, \mathrm{Na}$ which are favourable for the fixation of acid gas such as hydrogen sulfide [2830]. These wastes are rich in $\mathrm{CaCO}_{3}$ and can be reactive for the fixation of acid gas from the gas phase. A pure commercial calcite (Calcite) and activated carbon (AC) were also used as references. The performance of a single solid waste or AC was also compared with their mixtures containing different weight ratios of solid waste to AC.

\section{Materials and methods}

\subsection{Materials}

The initial materials used in this study were CCW-S and CCW-D wastes taken from two different industrial sites and were both in powdered form. They were sieved to eliminate particles larger than $315 \mu \mathrm{m}$ and dried at $105^{\circ} \mathrm{C}$ before each sorption test.

Pure calcite powder $\left(\mathrm{CaCO}_{3},>98 \mathrm{wt} \%\right)$ from Fisher Scientific and AC powder from CARBIO 12 SA (C1220 IG 91, >1100 $\mathrm{m}^{2} / \mathrm{g}$, France) were also used for $\mathrm{H}_{2} \mathrm{~S}$ removal test. The $\mathrm{AC}$ was grinded and sieved to recover particles smaller than $315 \mu \mathrm{m}$ for sorption test. These two sorbents are thereafter designated "Calcite" and "AC" for pure calcite and activated carbon, respectively.

\subsection{Methods}

Different chemical and physicochemical techniques were used for the characterizations and analysis of the sorbents before the $\mathrm{H}_{2} \mathrm{~S}$ removal test. Thermogravimetry-Differential scanning calorimetry coupling (TG-DSC) was performed in a SDTQ600 analyzer (TA Instruments) with a heating rate of $5^{\circ} \mathrm{C} / \mathrm{min}$ under air flux $(100 \mathrm{~mL} / \mathrm{min})$. X-ray diffraction (XRD) data of the solids were collected using a Phillips Panalytical X'pert Pro MPD diffractometer with a $\mathrm{Cu} \mathrm{K \alpha}(1.543 \AA)$ radiation source. This device works with a current of $45 \mathrm{kV}$ and an intensity of $40 \mathrm{~mA}$. Diffraction peaks have been recorded in the $2 \theta$ range of 10 to $70^{\circ}$ at $0.042^{\circ}$ per second. Specific surface area was determined by BET method, using a MICROMETRICS TriStar II 3020. The true density of the sorbents was carried out by a helium pycnometer (ACCUPYC 1330, Micrometrics). Particle size distribution was carried out using a Mastersizer 3000 laser diffraction particle size analyzer (Malvern Instrument). Inductively coupled plasma coupled with atomic emission spectrometry analysis (ICP-AES) was performed using HORIBA Jobin Yvon Ultima 2, for the elemental analysis. The ionic chromatography was performed with a Dionex ICS- 3000, equipped with a conductivity detector.

\subsection{Experimental set up}

The laboratory-scale setup was designed and assembled for the adsorption test. It consists mainly of three parts: gas feeding, adsorption unit (glass reactor, $200 \mathrm{~mL}$ ) and $\mathrm{H}_{2} \mathrm{~S}$ analyzer as shown in Fig. 1. Experiments were conducted in two phases, firstly with synthetic waste gas (based on dried air containing $200 \mathrm{ppmv}_{2} \mathrm{~S}$ ), and secondly with synthetic biogas from Linde France S.A, containing $\mathrm{CH}_{4}(64 \%), \mathrm{CO}_{2}$ (31\%), $\mathrm{H}_{2} \mathrm{~S}$ (200 ppmv) and balanced with $\mathrm{N}_{2}$ (around 5\%). All experiments were carried out at room temperature and atmospheric pressure. For a given experiment, $100 \mathrm{~mL}$ of demineralized water was introduced into the reactor. Then the synthetic waste gas or biogas containing 200 ppmv of $\mathrm{H}_{2} \mathrm{~S}$ was passed through the reactor at the flow rate of $100 \mathrm{~mL} / \mathrm{min}$ using a mass flow controller (SLA 5851, Brooks ${ }^{\circledR}$ Instrument). The reactor was kept under stirring along the experiment $(600 \mathrm{rpm})$.

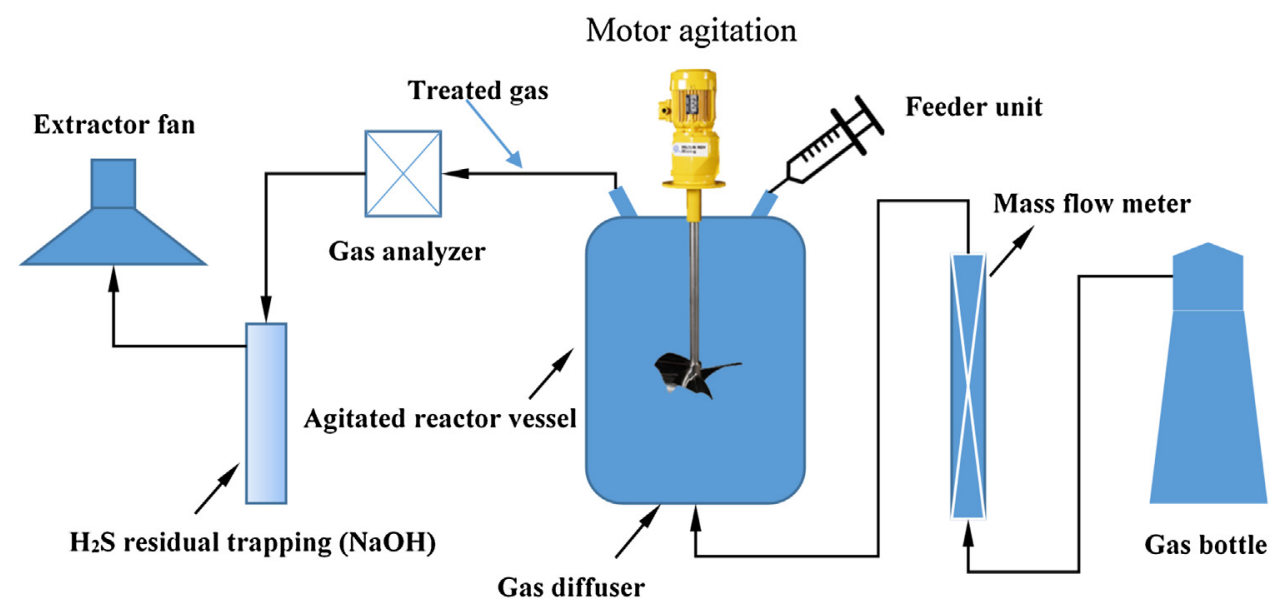

Fig 1. Flow diagram of laboratory-scale setup for $\mathrm{H}_{2} \mathrm{~S}$ removal from gas phase. 
For the removal of $\mathrm{H}_{2} \mathrm{~S}$ from air matrix, an electrochemical detector (GasAlertQuatro, from BW Technologies) was used to monitor and record $\mathrm{H}_{2} \mathrm{~S}$ concentration at the reactor outlet every $5 \mathrm{~s}$, with the detection limit of $0.1 \mathrm{ppmv}$. For the removal of $\mathrm{H}_{2} \mathrm{~S}$ from the biogas matrix, a $\mu$-GC (MyGC, Agilent) was used to analyze the gas sample taken from the outlet of the reactor. In fact, the synthetic biogas contained any trace of oxygen so the electrochemical detector, which needs $\mathrm{O}_{2}$ for the measurement, could not be used for this gas matrix. When the water was completely saturated with $\mathrm{H}_{2} \mathrm{~S}$ (by comparing the inlet and outlet concentration of $\mathrm{H}_{2} \mathrm{~S}$ ), 500 or $2500 \mathrm{mg}$ of sorbent was set into the reactor to start the sorption test. The experimental tests were validated by performing at least two sets. Sodium hydroxide ( $\mathrm{NaOH}$ ) was used to stripped $\mathrm{H}_{2} \mathrm{~S}$ and other contaminants from the exit gas effluent from the reactor, before discharging it through the ceiling extractor fan fixed directly above the reactor room.

In order to compare different experimental conditions with different sorbents, the total accumulated quantity of $\mathrm{H}_{2} \mathrm{~S}$ injected to the reactor at a given reaction time $\left(\mathrm{H}_{2} \mathrm{~S}_{\text {input }}, \mathrm{mg}\right)$ and the total accumulated quantity of $\mathrm{H}_{2} \mathrm{~S}$ fixed on the sorbent at a given reaction time (Accumulated sorbent, $\mathrm{mg}$ ) were defined and calculated from the Eqs. (1) and (2), respectively [28]

$\mathrm{H}_{2} \mathrm{~S}_{\text {input }}=\frac{P Q M}{10^{6} R T} C_{\text {int }} t$

Accumulated $_{\text {sorbent }}=\frac{P Q M}{10^{6} R T}\left[C_{\text {int }} t-\int_{0}^{t} C_{\text {out }} d t\right]$

Where, $Q$ is the inlet flow rate $(100 \mathrm{~mL} / \mathrm{min}), M$ is the molecular weight of $\mathrm{H}_{2} \mathrm{~S}(34.06 \mathrm{~g} / \mathrm{mol}), C_{\text {in }}$ is the inlet concentration of $\mathrm{H}_{2} \mathrm{~S}$ (200 ppmv), $C_{\text {out }}$ is the outlet concentration of $\mathrm{H}_{2} \mathrm{~S}$ (ppmv), $t$ is the reaction time ( $\mathrm{min}), P$ is the pressure of gas ( $1 \mathrm{~atm})$.

\section{Results and discussion}

\subsection{Characterization of the raw materials}

\subsubsection{ICP-AES}

The elemental analysis of CCW-S and CCW-D using ICP-AES technique is shown in Table 2. The commercial AC was not analyzed since it contains mainly carbon. It is seen from Table 2 that the commercial calcite was practically pure, as expected. $\mathrm{CaCO}_{3}$ was found to be the main component of CCW-S and CCW-D, but other elements were also present which include different metals, sulfur, and chlorine. CCW-D contained more impurities than CCW-S except for Fe. The content of organic compounds was negligible for both solid wastes.

\subsection{2. $X R D$}

Fig. 2 shows XRD patterns of the initial sorbents. For the commercial AC, two weak and broad peaks around 25 and $45^{\circ}$ were observed which are characterized for amorphous carbon-

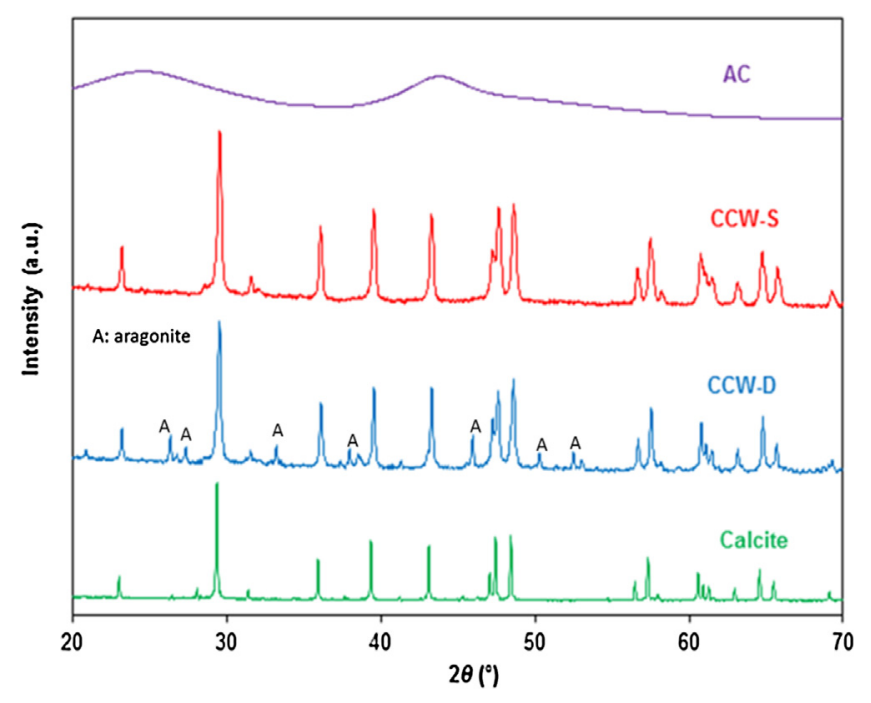

Fig. 2. XRD patterns of the sorbents showing aragonite and calcite; C: calcite; A: aragonite.

based material [29-31]. For the commercial calcite, only calcite was detected as the crystalline phase. CCW-S had the similar XRD pattern than that of the pure commercial calcite, which resulted from a long and deep natural carbonation. Well-crystalline calcite of rhombohedral structure was found to be the only major crystalline phase in this waste. On the other hand, CCW-D contained both calcite (rhombohedral structure) and aragonite (orthorhombic structure). The presence of aragonite is explained by a fast-artificial carbonation of CCW-D. The corresponding main peaks are indicated in Fig. 2.

\subsubsection{Thermogravimetric analysis (TG)}

This measures weight changes in a material as a function of temperature and/or time under a controlled atmosphere. Fig. 3 (a) presents the weight loss of the samples during a heating treatment from ambient temperature to $1000^{\circ} \mathrm{C}$ with a constant heating rate. For $\mathrm{CaCO}_{3}$-based sorbents, a weight loss between 610 and $800^{\circ} \mathrm{C}$ was observed. This corresponds to the decarbonation of the calcite (Eq. (3)), which was highly endothermic (Fig. 3 (b)). From this weight loss, the content of calcium carbonate could be determined as shown in Table 2 above. Between 200 and $610^{\circ} \mathrm{C}$, a small and continuous weight loss was also observed for all the $\mathrm{CaCO}_{3}$-based sorbents. This may be due to the decomposition of other carbonates at low contents (carbonates of sodium, magnesium etc.).

$\mathrm{CaCO}_{3} \rightarrow \mathrm{CaO}+\mathrm{CO}_{2}$

For the commercial AC, a slight weight loss (13.4\%) was observed around $100^{\circ} \mathrm{C}$ which corresponds to the surface

Table 2

Main chemical composition of residues (CCW-S, CCW-D) and reference Calcite.

\begin{tabular}{|c|c|c|c|c|c|c|c|c|}
\hline \multirow[t]{2}{*}{ Materials } & \multicolumn{7}{|c|}{ Concentration (g/kg) } & \multirow[t]{2}{*}{ Total $(\mathrm{g} / \mathrm{kg})$} \\
\hline & $\mathrm{Ca}$ & $\mathrm{CO}_{3}{ }^{2-\mathrm{b}}$ & S & $\mathrm{Mg}$ & $\mathrm{Na}$ & $\mathrm{Fe}$ & Others $^{a}$ & \\
\hline Calcite & $434.5 \pm 1.2$ & $576 \pm 0.4$ & - & - & - & - & - & $1010.5 \pm 1.6$ \\
\hline CCW-S & $384.2 \pm 2.7$ & $558 \pm 1.1$ & $1.1 \pm 1.0$ & $1.3 \pm 0.7$ & $3.6 \pm 1.0$ & $3.9 \pm 0.4$ & 0.47 & $952.1 \pm 6.9$ \\
\hline CCW-D & $357.4 \pm 2.5$ & $508 \pm 3.4$ & $7.2 \pm 2.6$ & $2.4 \pm 1.2$ & $9.9 \pm 3.2$ & $1.6 \pm 0.6$ & 0.40 & $886.5 \pm 13.5$ \\
\hline
\end{tabular}

a $\mathrm{P}, \mathrm{Cu}, \mathrm{Mn}, \mathrm{Zn}, \mathrm{Sn}, \mathrm{Al}, \mathrm{Cl}, \mathrm{Si}$.

b Determined by thermogravimetric Analysis. 

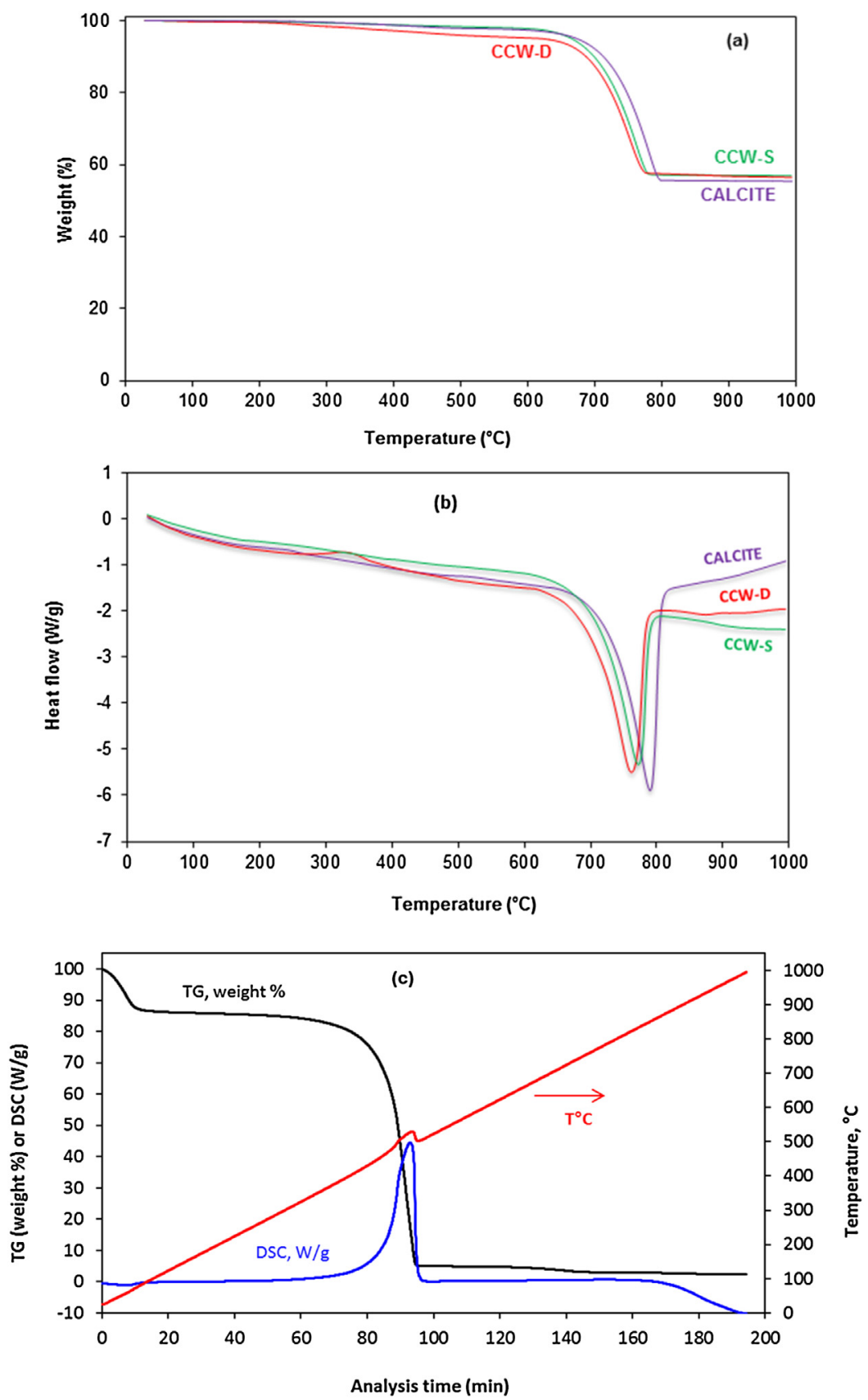

Fig. 3. TG-DSC curves of the sorbents under air atmosphere. (a) and (b): TG and DSC signal of calcium carbonate-based sorbents; (c): TG-DSC of AC.

humidity of AC (Fig. 3(c)). The high quantity of humidity of this material is explained by its high specific surface area $\left(1100 \mathrm{~m}^{2} / \mathrm{g}\right)$. A weight loss was then observed above $380^{\circ} \mathrm{C}$, due to the combustion of AC. This combustion was strongly exothermic which disturbed the furnace temperature, despite the small amount of sample used for this analysis ( $16.6 \mathrm{mg}$ only). A small weight loss was also recorded above $650^{\circ} \mathrm{C}$ which was due to the gasification of coke deposition. Low ash content $(<3 \%)$ was observed for this AC indicating its high purity.

\subsubsection{Particle size distribution}

Fig. 4 shows the particle size distribution of all the raw materials before pretreatment. The commercial calcite had a bimodal distribution with two peaks around 0.8 and $10 \mu \mathrm{m}$. The particle size distribution of this sample extended from 0.1 to about $45 \mu \mathrm{m}$. The CCW-S and CCW-D show a multimodal distribution that extended from 0.1 to $590 \mu \mathrm{m}$, but the main peak was also found around $10 \mu \mathrm{m}$. Finally, the commercial AC presented a multimodal distribution with a broad peak. The main peak is located around $210 \mu \mathrm{m}$. Table 3 shows the values of the characteristic diameters $\left(d_{50}\right.$ and $d_{90}$ ) of the powders. The average diameter $\left(d_{50}\right)$ is the same order of magnitude for the three calcium carbonates, which was smaller than that of AC.

Part of the objective of this research is to valorize the entire volume of residue. To ensure proper suspension of the solid in the lab-scale reactor used in this work $(200 \mathrm{~mL})$ and thus to avoid the deposition of solids at the bottom of the reactor, the solids were sifted. At laboratory scale, the fraction of solid used was less than 


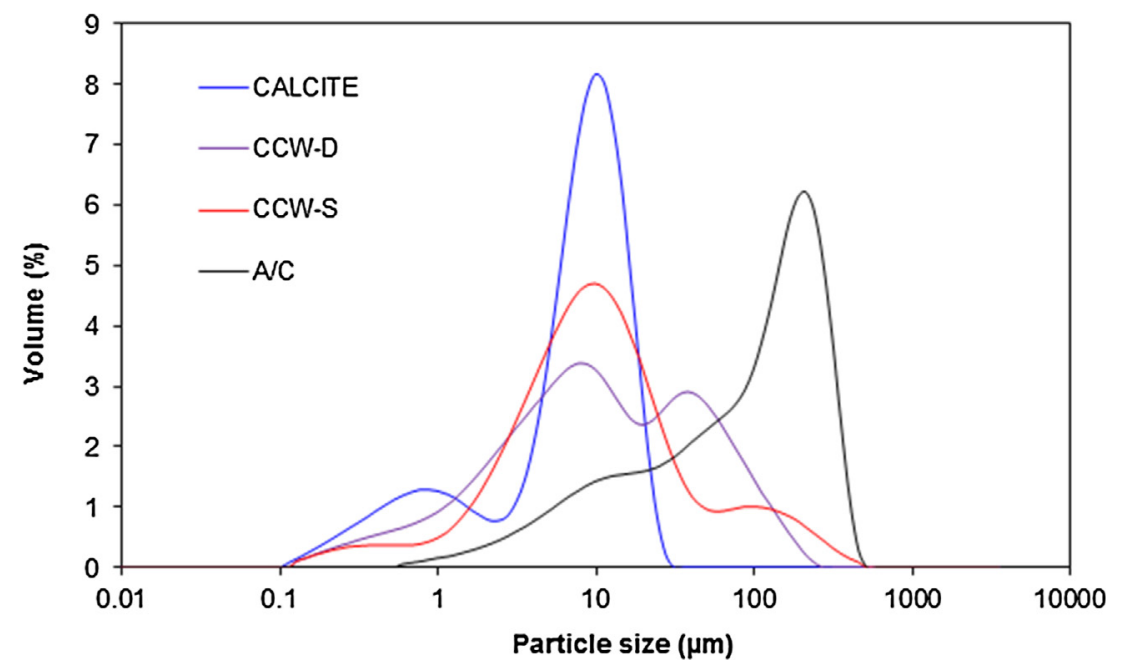

Fig. 4. Particle size distributions by volume of Calcite, CCW-D, CCW-S, and Activated carbon (AC).

$315 \mu \mathrm{m}$ as previously mentioned. This fraction corresponds to $99 \%$ by volume of the two residues.

\subsubsection{True density $\mathcal{E}$ specific surface area}

The specific surface area and the true density of the sorbents are shown in Table 4. All the initial calcium carbonate-based sorbents (Calcite, CCW-D, and CCW-S) had a specific surface area lower than $4 \mathrm{~g} / \mathrm{m}^{2}$, while that of AC reached $1098 \mathrm{~g} / \mathrm{m}^{2}$. The true density of the calcium carbonate-based sorbents was similar to each other, while that of AC was smaller. This is explained by the low density of carbon matrix of AC compared to calcium carbonate of other sorbents.

\subsection{Sorption reactivity in the removal of $\mathrm{H}_{2} \mathrm{~S}$ in air matrix}

As stated earlier, $\mathrm{H}_{2} \mathrm{~S}$ can be physically adsorbed, and chemically absorbed due to the presence of some metals, which can act as catalysts or reagents, and also the surface alkalinity of sorbent. Fig. 5(a,b) present the results obtained for the removal of $\mathrm{H}_{2} \mathrm{~S}(200$ ppmv) in dry air matrix.

In Fig. 5(a), which presents the outlet concentration of $\mathrm{H}_{2} \mathrm{~S}$ as a function of the reaction time, the pure commercial calcite had the lowest reactivity for $\mathrm{H}_{2} \mathrm{~S}$ removal. The outlet concentration of $\mathrm{H}_{2} \mathrm{~S}$ was measured by the $\mu$-GC for this experiment which explained the limited number of analyzed points, but it can be seen that the suspension of pure calcite quickly lost its reactivity above the first two hours of reaction. Among the two solid wastes, CCW-S presented lower reactivity than CCS-D. Both solid wastes quickly decreased the concentration of $\mathrm{H}_{2} \mathrm{~S}$ to about $8 \mathrm{ppmv}$ at the outlet of the reactor for the first min of reaction. Then the outlet concentration of $\mathrm{H}_{2} \mathrm{~S}$ progressively increased and stagnated around 45-50 ppmv for CCW-D and 150 ppmv for CCW-S. Taking into account the low specific surface area of calcium carbonate-based sorbents, it is expected that the physical adsorption of $\mathrm{H}_{2} \mathrm{~S}$ on the surface of these sorbents is not enough for explaining the stagnant period, observed for both solid wastes. Previous work of our team explained this phenomenon by the catalytic oxidation of $\mathrm{H}_{2} \mathrm{~S}$, catalyzed by various metals present in these solid wastes (Ca, $\mathrm{Mg}$, Fe etc.) [32]. The acid-basic reaction of $\mathrm{H}_{2} \mathrm{~S}$ with soluble carbonate species (mainly $\mathrm{CO}_{3}{ }^{2-}$ ) in the aqueous solution plays also important role for the performance of these solid wastes. In the case of CCW-S, the outlet concentration of $\mathrm{H}_{2} \mathrm{~S}$ decreased again above $370 \mathrm{~min}$. It is supposed that a secondary dissolution of $\mathrm{CaCO}_{3}$-based particles of this sorbent took place leading to the supplementary availability of active species for the removal of $\mathrm{H}_{2} \mathrm{~S}$. The higher reactivity of CCW-D compared to CCW-S could be explained by the presence of aragonite (which was not presented in CCW-S), as well as the high amount of impurities of CCW-D. Aragonite is more soluble in water than calcite which leads to high availability of carbonate anions for the neutralization of sulfide species, while the impurities (mostly metals and metal oxides) catalyze the oxidation of sulfide species with dissolved oxygen as oxidant.

For the commercial AC, the outlet concentration of $\mathrm{H}_{2} \mathrm{~S}$ decreased to zero and was kept at this value for up to $175 \mathrm{~min}$. Then it slowly increased and reached 25 ppmv after $420 \mathrm{~min}$. So, AC was more performant than the solid wastes during the first minutes of reaction. But it seemed that AC continuously lost its reactivity suggesting the physical adsorption of $\mathrm{H}_{2} \mathrm{~S}$ as the predominant phenomenon. On the other hand, calcium carbonate-based wastes allowed keeping constantly the removal of $\mathrm{H}_{2} \mathrm{~S}$ thanks to the catalytic oxidation as the predominant step.

Fig. 5(b) represents the results obtained in Fig. 5 (a) by the accumulated quantity of $\mathrm{H}_{2} \mathrm{~S}$ fed into the reactor or fixed by the sorbents. This also allows comparing the performance of the sorbents, and specifically the calculation of the quantity of $\mathrm{H}_{2} \mathrm{~S}$
Table 3

Values of the diameters $d_{50}$ and $d_{90}$ of the initial sorbents.

\begin{tabular}{lll}
\hline Materials & $d_{50}(\mu \mathrm{m})$ & $d_{90}(\mu \mathrm{m})$ \\
\hline Calcite & 8.9 & 17 \\
CCW-S & 10.2 & 75.9 \\
CCW-D & 11.2 & 74.3 \\
AC & 24.9 & 108 \\
\hline
\end{tabular}

Table 4

The surface area and the density of the sorbents.

\begin{tabular}{lll}
\hline Materials & Surface Area $\left(\mathrm{g} / \mathrm{m}^{2}\right)$ & Average Density $\left(\mathrm{g} / \mathrm{m}^{3}\right)$ \\
\hline Calcite & 2.60 & 2.73 \\
CCW-S & 3.23 & 2.76 \\
CCW-D & 3.98 & 2.70 \\
Active Carbon & 1098 & 2.01 \\
\hline
\end{tabular}



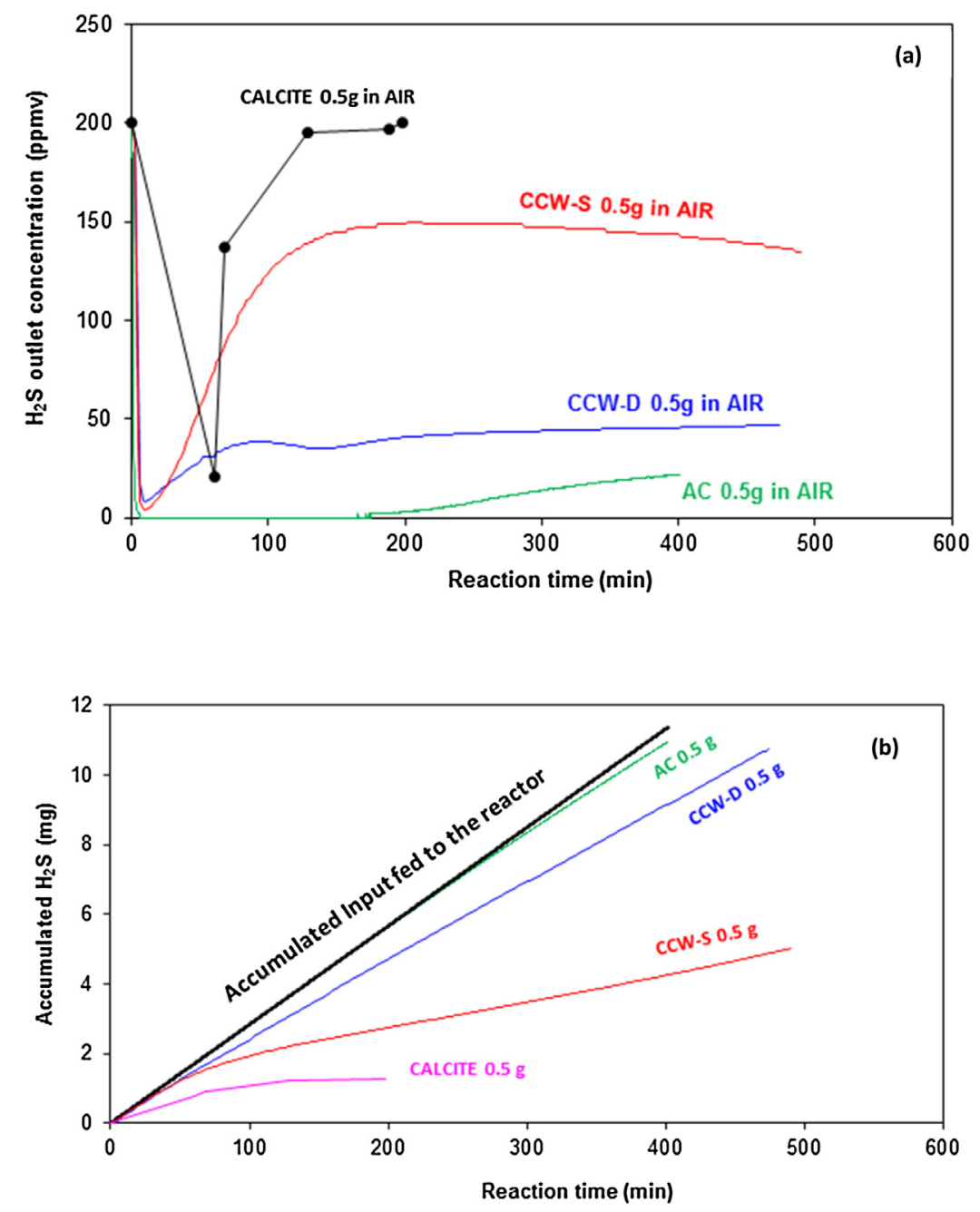

Fig. 5. Experimental results in $\mathrm{H}_{2} \mathrm{~S}$ passing over the sorbents (AC, CALCITE, CCW-D and CCW-S) for the removal of $\mathrm{H}_{2} \mathrm{~S}$ (200 ppmv) diluted in air with experimental conditions of room temperature and pressure, $500 \mathrm{mg}$ of sorbent, $100 \mathrm{~mL} / \mathrm{min}$ of input gas, $100 \mathrm{~mL}$ of water: (a): Outlet concentration of $\mathrm{H}_{2} \mathrm{~S}$; (b): Accumulated quantity of $\mathrm{H}_{2} \mathrm{~S}$ fixed on sorbent.

fixed by the sorbent at a given reaction time. The curve of the accumulated quantity of $\mathrm{H}_{2} \mathrm{~S}$ fixed by AC was superposed or mostly close to the curve of the accumulated quantity of $\mathrm{H}_{2} \mathrm{~S}$ introduced to the reactor during the reaction time. So, most $\mathrm{H}_{2} \mathrm{~S}$ introduced to the reactor was fixed by this sorbent. By the same analysis, CCW-D was more performant than CCW-S and pure calcite. Basing on the results in Fig. 5(a,b), only the commercial AC and CCW-D were selected for the study of $\mathrm{H}_{2} \mathrm{~S}$ removal in biogas matrix below.

\subsection{Sorption reactivity in the removal of $\mathrm{H}_{2} \mathrm{~S}$ in biogas matrix}

The synthetic biogas containing was $\mathrm{CH}_{4}(64 \%), \mathrm{CO}_{2}(31 \%), \mathrm{H}_{2} \mathrm{~S}$ (200 ppmv), and balanced with $\mathrm{N}_{2}$ (around 5\%), and was obtained from Linde France SA. The removal of $\mathrm{H}_{2} \mathrm{~S}$ in this biogas matrix was performed with two sorbents AC and CCW-D. Fig. 6 (a) shows the outlet concentration of $\mathrm{H}_{2} \mathrm{~S}$ obtained with 0.5 or $2.5 \mathrm{~g}$ of the individual sorbents. Note that using the $\mu$-GC analysis with manual injection, there was less analysis point compared to the electrochemical detector. In all case, CCW-D had lower reactivity than AC. For both quantities of CCW-D of 0.5 and $2.5 \mathrm{~g}$, the profile of the outlet concentration of $\mathrm{H}_{2} \mathrm{~S}$ was quite similar. This is explained by the fact that the synthetic biogas did not contain oxygen so no oxidation of sulfide species took place. Dissolved $\mathrm{H}_{2} \mathrm{~S}$ could only be neutralized by carbonate anions $\left(\mathrm{CO}_{3}{ }^{2-}\right)$ coming from the dissolution of calcium carbonate and this is slow because calcium carbonate (in both calcite and aragonite forms) has low water solubility. The physisorption of $\mathrm{H}_{2} \mathrm{~S}$ must be low in this case, because CCW-D had very low specific surface area and was not porous. Thus, the outlet concentration of $\mathrm{H}_{2} \mathrm{~S}$ progressively increase and was close to the inlet value after $540 \mathrm{~min}$ of test. In combination with the results in the air matrix, we can see that the catalytic oxidation is predominant when using calcium carbonate wastes as sorbents. In fact, the analysis of the liquid phase recovered after test in the air matrix evidenced the formation of oxidation products (sulfate, sulfite, and thiosulfate). This was previously detailed [32]. On the other hand, physisorption, which is favourable by high specific surface area such as the case of AC used in this work $\left(1098 \mathrm{~m}^{2} / \mathrm{g}\right)$, must be predominant when using $A C$ as sorbent. This is not (or less) affected by the presence or absence of oxygen in the gas matrix. The increase of the quantity of $\mathrm{AC}$ from 0.5 to $2.5 \mathrm{~g}$ thus allowed strongly decreasing the outlet concentration of $\mathrm{H}_{2} \mathrm{~S}$ during the reaction. After $540 \mathrm{~min}$, the outlet concentration of $\mathrm{H}_{2} \mathrm{~S}$ was 157 and $27 \mathrm{ppmv}$ using 0.5 and $2.5 \mathrm{~g}$ of AC, respectively. Fig. 6(b) represents the results obtained in Fig. 6(a) by the accumulated quantity of $\mathrm{H}_{2} \mathrm{~S}$. The effect of gas matrix on the performance of the process was again evidenced. 

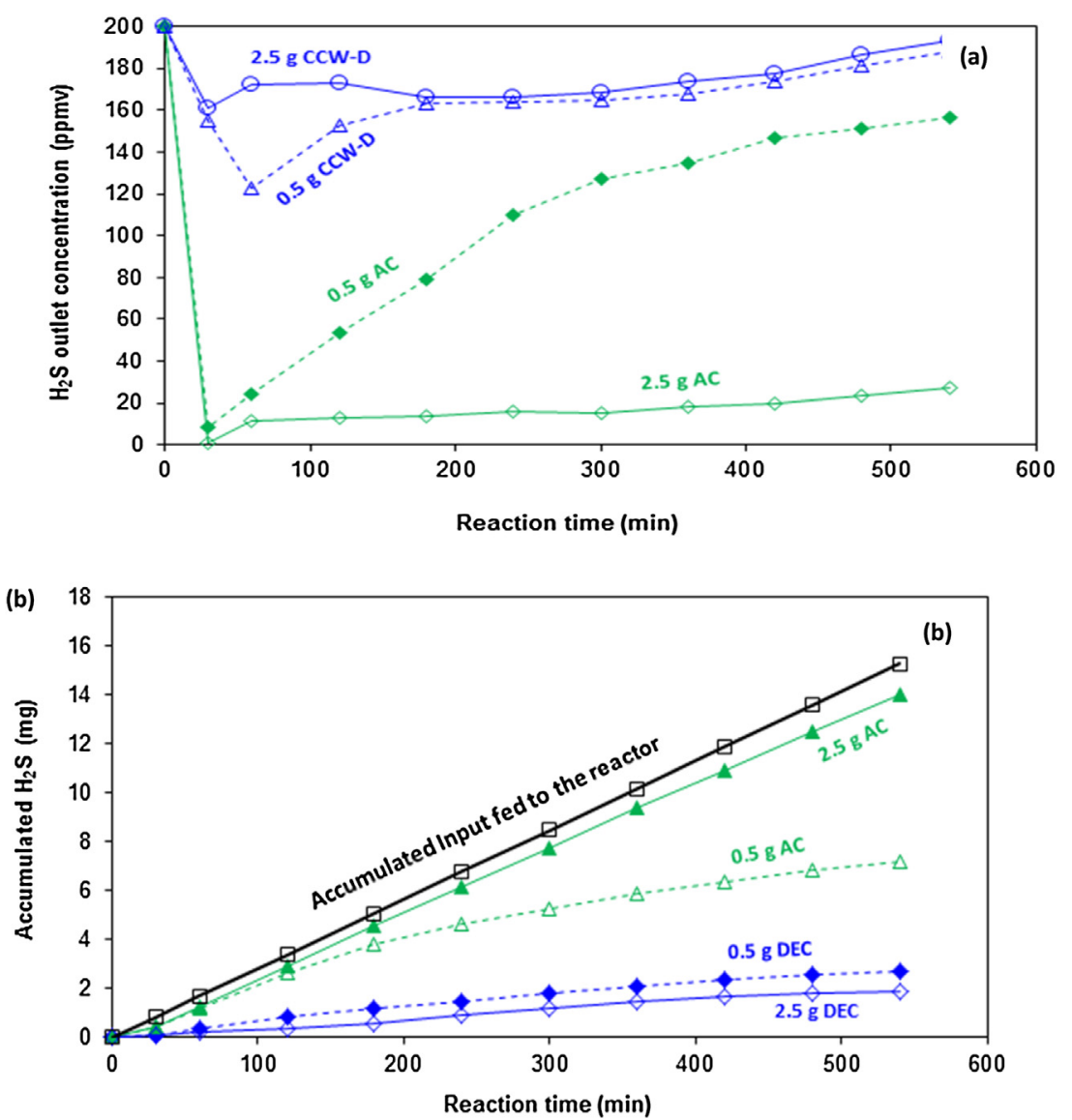

Fig. 6. Experimental results in $\mathrm{H}_{2} \mathrm{~S}$ passing over the sorbents ( $\mathrm{AC}$ and $\left.\mathrm{CCW}-\mathrm{D}\right)$ for the removal of $\mathrm{H}_{2} \mathrm{~S}\left(200\right.$ ppmv) in biogas matrix $\left(\mathrm{CH}_{4}=64 \%\right.$, $\mathrm{CO}{ }_{2}=31 \%$, $\left.\mathrm{N}_{2}=5 \%\right)$, with experimental conditions of room temperature and pressure, 2500 and $500 \mathrm{mg}$ of sorbent, $100 \mathrm{~mL} / \mathrm{min}$ of input gas, $100 \mathrm{~mL}$ of water: (a): Outlet concentration of $\mathrm{H}_{2} \mathrm{~S}$; (b): Accumulated quantity of $\mathrm{H}_{2} \mathrm{~S}$ fixed on sorbent.

When $0.5 \mathrm{~g}$ AC was used, the performance was higher with air matrix (11 $\mathrm{mg}$ of $\mathrm{H}_{2} \mathrm{~S}$ accumulated on the sorbent after 400 min of reaction time, Fig. 5(b)) than with biogas matrix (versus $6 \mathrm{mg}$ of $\mathrm{H}_{2} \mathrm{~S}$ accumulated on the sorbent after 400 min of reaction time, Fig. 6(b)). In fact, in Fig. 5(a), a stagnant period at zero ppmv for 175 min was observed with the air matrix but it was not the case with the biogas matrix. Taking into account the composition of the synthetic biogas used in this work, mostly with the presence of $\mathrm{CH}_{4}$ and $\mathrm{CO}_{2}$, it is supposed that these two molecules had competitive adsorption against $\mathrm{H}_{2} \mathrm{~S}$. Thus, it decreased the performance of $\mathrm{AC}$ in the biogas matrix for the fixation of $\mathrm{H}_{2} \mathrm{~S}$. The composition of the biogas was all analyzed during the reaction. The significant change of its composition (for $\mathrm{CO}_{2}, \mathrm{CH}_{4}$ and $\mathrm{N}_{2}$ ) was not observed, probably due to high contents of these gases. The reactivity of $\mathrm{AC}$ for the adsorption of $\mathrm{CO}_{2}$ and $\mathrm{CH}_{4}$ should be further done in order to evidence their impact on the reactivity of $\mathrm{AC}$ for $\mathrm{H}_{2} \mathrm{~S}$ fixation.

Table 5

Composition of different mixtures of AC and CCW-D used in this work.

\begin{tabular}{lll}
\hline Designation & Weight ratio of AC to CCW-S & Total weight, g \\
\hline AC3:CCW-D1 & $3: 1$ & 2.5 \\
AC2:CCW-D1 & $2: 1$ & 2.5 \\
AC1:CCW-D1 & $1: 1$ & 2.5 \\
AC1:CCW-D2 & $1: 2$ & 2.5 \\
AC1:CCW-D3 & $1: 3$ & 2.5 \\
\hline
\end{tabular}

\subsection{Sorption reactivity of mixed sorbents in biogas matrix}

The results obtained above with the single sorbents (AC or calcium carbonate-based material) show that each sorbent had its own interaction with $\mathrm{H}_{2} \mathrm{~S}$. For $\mathrm{AC}$, the physisorption was predominant. For calcium carbonate-based material, the catalytic oxidation, enhanced by acid-basic reaction, mainly took place. It is useful to focus on the investigation of the reactivity of different mixture of AC and CCW-D for the removal of $\mathrm{H}_{2} \mathrm{~S}$ from the biogas matrix. For this, only one sorbent quantity was used $(2.5 \mathrm{~g})$. Five sorbent mixtures were tested with the weight ratio of AC to CCW-D equal to $1: 1 ; 1: 2 ; 2: 1,1: 3$; and $3: 1$, by keeping the total weight of $2.5 \mathrm{~g}$ (Table 5). Fig. 7(a) shows the outlet concentration of $\mathrm{H}_{2} \mathrm{~S}$ as a function of the reaction time obtained with these mixtures. The results obtained with the individual CCW-D or AC also included for comparison. Fig. 7(b) represents the results of Fig. 7(a) by the accumulated quantity of $\mathrm{H}_{2} \mathrm{~S}$.

In Fig. 7(a), it can be seen that the increase of the AC content led to the improvement of the performance of the mixture. Thus the order of the reactivity of these mixtures could be classed as following: $\mathrm{AC} 3: \mathrm{CCW}-\mathrm{D} 1>\mathrm{AC} 2 \mathrm{CCW}-\mathrm{D} 1>\mathrm{AC} 1 \mathrm{CCW}-\mathrm{D} 1 \approx$ individual $\mathrm{AC}>\mathrm{AC1}: \mathrm{CCW}-\mathrm{D} 2 \approx \mathrm{AC1}: \mathrm{CCW}-\mathrm{D} 3>$ individual CCW-D. In fact, after 540 min of reaction time, the quantity of $\mathrm{H}_{2} \mathrm{~S}$ accumulated in each sorbent was: $15 \mathrm{mg}$ for AC3:CCW-D1,14.5 mg for AC2:CCWD1, $14 \mathrm{mg}$ for $\mathrm{AC} 1$ :CCW-D1 and $\mathrm{AC}$ alone, $10.5 \mathrm{mg}$ for AC1:CCW-D2, $10 \mathrm{mg}$ for $\mathrm{AC} 1: \mathrm{CCW}-\mathrm{D} 3$ and $2 \mathrm{mg}$ for CCW-D alone. At $30 \mathrm{~min}$ of reaction, the outlet concentration of $\mathrm{H}_{2} \mathrm{~S}$ was already 5.6-7.3 ppmv, 

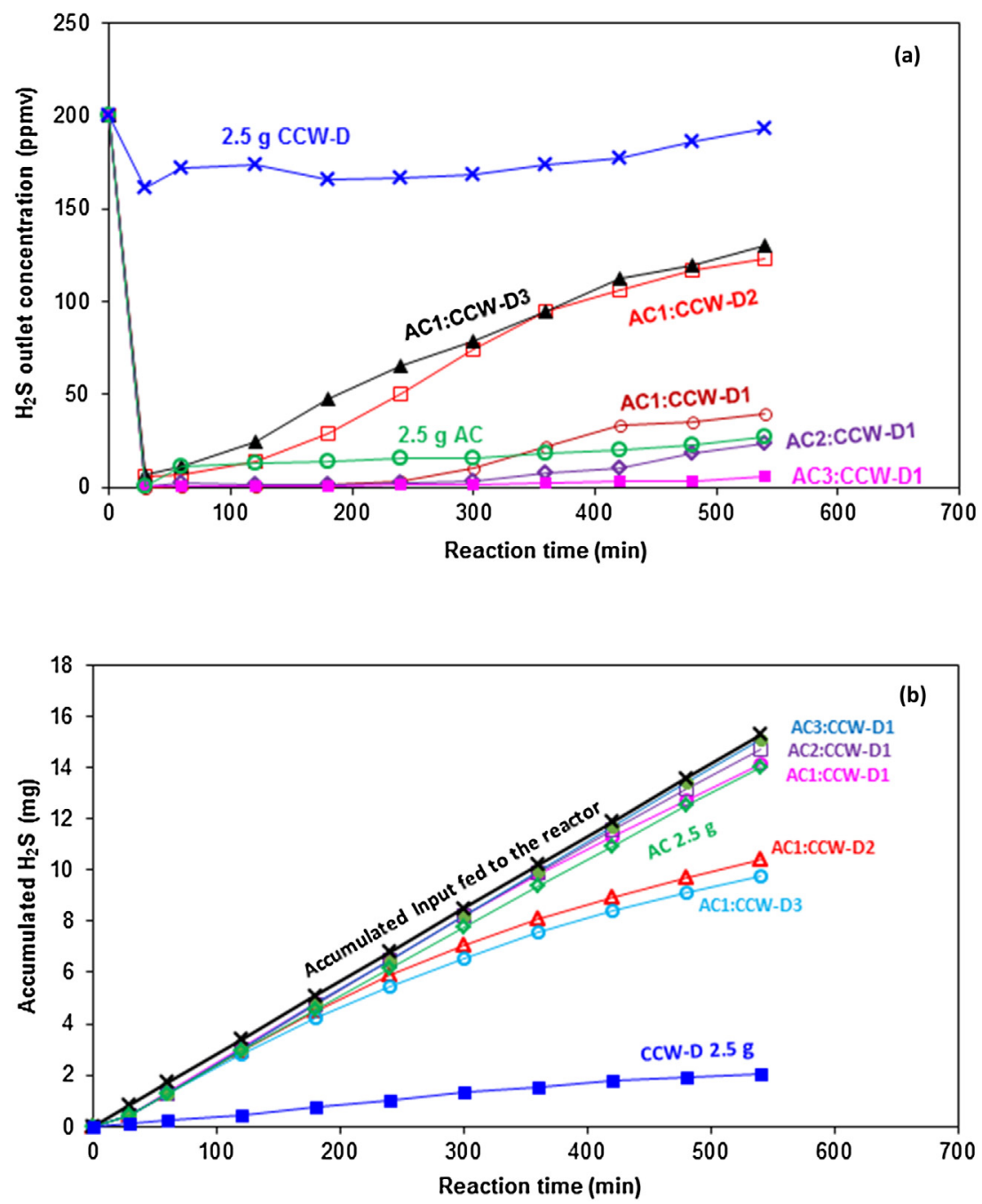

Fig. 7. Experimental results in $\mathrm{H}_{2} \mathrm{~S}$ passing over mixtures of sorbents ( $\left.\mathrm{AC}: \mathrm{CCW}-\mathrm{D}\right)$ for the removal of $\mathrm{H}_{2} \mathrm{~S}(200 \mathrm{ppmv})$ in biogas matrix $\left(\mathrm{CH}_{4}=64 \%, \mathrm{CO}_{2}=31 \%, \mathrm{~N}_{2}=5 \%\right)$, with experimental conditions of room temperature and pressure, $2500 \mathrm{mg}$ of sorbents (weight ratio of AC to CCW-D of 1:1, 2:1,1:2,1:3 and 3:1), 100 mL/min of input gas, 100 mL of water: (a): Outlet concentration of $\mathrm{H}_{2} \mathrm{~S}$; (b): Accumulated quantity of $\mathrm{H}_{2} \mathrm{~S}$ fixed on sorbent.

which progressively rose to $123-130 \mathrm{ppm}$ at $540 \mathrm{~min}$. An important change in the performance was obtained when using the mixture containing $50 \mathrm{wt} \%$ of AC (AC1:CCW-D1). This mixture reached the practically-complete removal of $\mathrm{H}_{2} \mathrm{~S}$ for at least the first $180 \mathrm{~min}$. Then this mixture slowly lost its reactivity but it was comparable to the individual $\mathrm{AC}$ at the same total weight of $2.5 \mathrm{~g}$. The increase of the AC content to $66.7 \%$ (AC2:CCW-D1) and $75 \%$ (AC3:CCW-D1) allowed still increasing the performance of the process. At $75 \%$ of $\mathrm{AC}$, the outlet concentration of $\mathrm{H}_{2} \mathrm{~S}$ was kept close to zero for more than $480 \mathrm{~min}$ and was only of 5.6 ppmv after $540 \mathrm{~min}$. This mixture was much more performant than the individual AC or CCW-D, which suggests a very interesting synergy effect of the mixture for the removal of $\mathrm{H}_{2} \mathrm{~S}$.

\subsection{Discussion}

Two solid wastes (CCW-D and CCW-S) containing mainly calcium carbonate were investigated in the removal of $\mathrm{H}_{2} \mathrm{~S}$ from the gas phase. Under the air matrix, they were reactive because of the availability of basic species (carbonate anions) for the neutralization of sulfide species, and the catalytic activity of various metals initially present in these wastes. They were more reactive than a pure commercial calcite. However, under the reducing atmosphere of biogas, without oxygen, these solid wastes had only low reactivity, explained by the absence of oxidation reactions.

The commercial AC used as reference in this work was found to be efficient for the removal of $\mathrm{H}_{2} \mathrm{~S}$ from both air and biogas matrix. However, when AC and CCW-D were combined, the performance was highly improved compared to the individual sorbents in the biogas matrix. The synergy effect of this combination might be explained by the physico-chemical properties of the two sorbents. CCW-D, containing mainly calcium carbonate, has high basicity. This allowed accelerating the dissolution and dissociation of $\mathrm{H}_{2} \mathrm{~S}$ from the gas phase to the liquid phase. But this was not enough to maintain the abatement of $\mathrm{H}_{2} \mathrm{~S}$ with the reaction time under the biogas matrix because dissolved sulfide species were accumulated in the reactor (without oxidation reactions). The combination with AC allowed the fixation of dissolved sulfide species and thus improved the fixation rate of $\mathrm{H}_{2} \mathrm{~S}$.

In the aqueous solution, $\mathrm{H}_{2} \mathrm{~S}$ can simply exist under the dissolved form $\left(\mathrm{H}_{2} \mathrm{~S}_{\mathrm{aq}}\right)$ or can be dissociated to $\mathrm{HS}^{-}$and $\mathrm{S}^{2-}$, as a function of the $\mathrm{pH}$. The favourable effect of CCW-D on the reactivity of AC suggests that the dissociative forms of sulfides $\mathrm{HS}^{-}, \mathrm{S}^{2-}$ 
might be preferentially adsorbed on the surface of AC. In this case, the basicity of the solid waste is useful for the neutralization of protons coming from the dissociation of $\mathrm{H}_{2} \mathrm{~S}$.

In Fig. 7(a), the mixture AC3:CW-D1 (composed of $1.875 \mathrm{~g}$ of $\mathrm{AC}$ and $0.625 \mathrm{~g}$ of CCW-D) and the mixture AC2:CW-D1 (composed of $1.667 \mathrm{~g}$ of $\mathrm{AC}$ and $0.833 \mathrm{~g}$ of CCW-D) show higher reactivity than the individual $A C$, at the same sorbent weight used $(2.5 \mathrm{~g})$. The mixture AC:CW-D1 (composed of $1.25 \mathrm{~g}$ of AC and $1.25 \mathrm{~g}$ of CCW-D) had the comparable reactivity than the individual AC. Taking into account the high cost of commercial AC compared to calcium carbonate-based waste, it is very interesting to combine these two materials for the design of new performance and low cost sorbent. More importantly, considering the important annual production of sodium carbonate and sodium bicarbonate (about 60 million tons worldwide in 2014 [33]), large quantities of calcium carbonatebased wastes are generated annually. The high availability, the low cost and the good reactivity for the fixation of acid gas of these wastes are important criteria for the viability of the process. In addition, up-to-date, these wastes are not valorized for any useful material. The biogas purification may open new route for the valorization of these wastes, which have been creating problems for ammonia soda plants [34-36].

Fig. 8 shows the evolution of the concentration of $\mathrm{CH}_{4}, \mathrm{CO}_{2}, \mathrm{~N}_{2}$ and $\mathrm{H}_{2} \mathrm{~S}$ with the reaction time using the mixture AC3:CCW-D1 in the biogas matrix. Both $\mathrm{CH}_{4}$ and $\mathrm{CO}_{2}$ concentration levels were rather stable throughout the experiment, which was very positive for the study. It means that the sorbents developed in this work has high selectivity and compatibility towards polar compounds, such as $\mathrm{H}_{2} \mathrm{~S}$ and therefore more appropriate for $\mathrm{H}_{2} \mathrm{~S}$ removal.

In this work, the only pretreatment applied to the solid wastes was the drying at $105^{\circ} \mathrm{C}$ to remove moisture, because of the nature of the waste material storage, which is mostly stored outside with or without covers. It is possible to increase the performance of the sorbent by thermally treating it at higher temperature. Thermal treatment is known as an efficient treatment for desorbing molecules adsorbed on the surface of a given solid as well as for combustion of eventual organic molecules present in the initial sorbents. In the case of calcium carbonate-based sorbent, at high temperature (above $610^{\circ} \mathrm{C}$ ), the decarbonation takes place and increases the basicity and so the reactivity of this material. Further work will focus on the influence of the thermal treatment on the reactivity of calcium carbonate-based sorbents.

Actually, there are different novel aspects of the present study. First, $\mathrm{H}_{2} \mathrm{~S}$ removal test was carried out with two different gas matrix, which represent gaseous effluent (air matrix) or biogas. This allows identifying the impact of $\mathrm{CO}_{2}$ (and $\mathrm{CH}_{4}$ ) on the fixation of $\mathrm{H}_{2} \mathrm{~S}$ under the similar operational conditions. The use of the triphasic gas/liquid/solid process for gas cleaning seemed to be also a novelty of this work. This accelerates the transfer of $\mathrm{H}_{2} \mathrm{~S}$ from gas to liquid phase which is favourable for the contact of sulfide species with the sorbents. Finally, an important aspect of the study is the use of mixtures of activated carbon with calcium carbonate waste as new sorbents for sorption test. These mixtures had higher reactivity than $A C$ or solid waste alone. It is believed that the reduction in the quantity of $A C$, that will be required for biogas treatment as a result of substituting it with low cost waste materials as sorbents will lead to reduction in cost of AC, thereby leading to overall reduction biogas purification and upgrading costs.

The results of the current study agreed with earlier works of our team and other researchers on $\mathrm{H}_{2} \mathrm{~S}$ removal from gas phase. Galera Martinez [32] worked on valorization of industrial carbonate residues for the treatment of hydrogen sulfide in gas effluents, and explained the catalytic oxidation of $\mathrm{H}_{2} \mathrm{~S}$, catalyzed by various metals present in these solid wastes (Ca, Mg, Fe etc.). Also, Stita et al. [37] studied metal-doped apatitic calcium phosphates for the removal of hydrogen sulfide from gas phase, while Pham Xuan et al. [28] studied on the valorization of calcium carbonate-based solid wastes for the treatment of hydrogen sulfide from gas phase. Lastly, Pham Minh et al. [38] conducted the similar research based on calcium phosphate-based materials starting from calcium carbonate and orthophosphoric acid for the removal of lead(II) from an aqueous solution. In addition to these, Lasocki [39] investigated biogas treatment by removal of hydrogen sulfide and carbon dioxide at laboratory-scale, using both absorptions in liquid phase (barbotage process) and solid bed of reagent. Also, $\mathrm{H}_{2} \mathrm{~S}$ removal from biogas on sludge-derived adsorbents was investigated by other researchers [24,40-42], using similar techniques. These earlier investigations and other studies in the literature were based solely on synthetic waste gas matrix $\left(\mathrm{H}_{2} \mathrm{~S}\right.$ in air) only, except

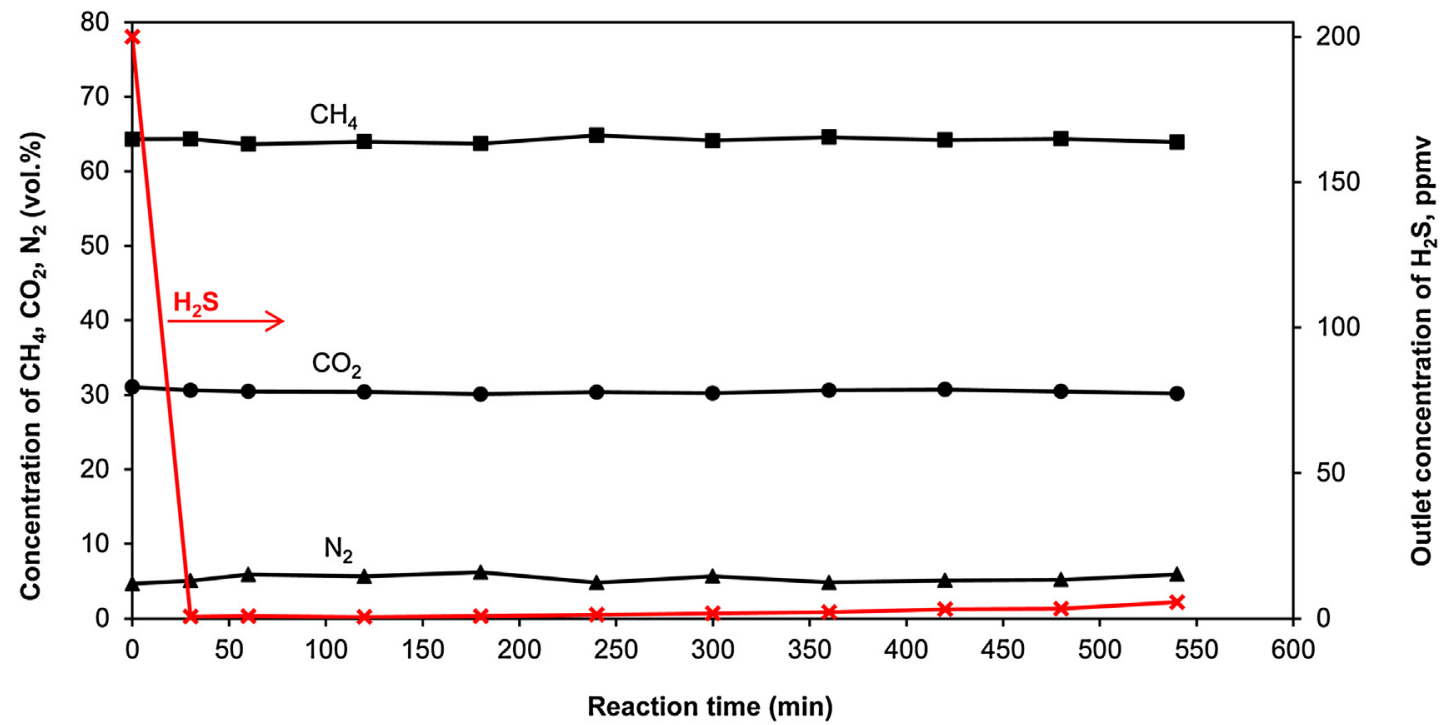

Fig. 8. Evolution of the concentration of $\mathrm{CH}_{4}, \mathrm{CO}_{2}, \mathrm{~N}_{2}$ and $\mathrm{H}_{2} \mathrm{~S}$ at the outlet of the reactor as a function of the reaction time when using the mixture $\mathrm{AC} 3$ : $\mathrm{CCW}$-D1 in the biogas matrix. 
Ortiz [24], who used simulated biogas. This might be due to the fact that $\mathrm{CO}_{2}$ might compete against $\mathrm{H}_{2} \mathrm{~S}$ in adsorption depending on the porous structure of the adsorbent and the alkali constituents since they are both acid gases. Whereas this study was based on both simulated biogas matrix $\left(\mathrm{H}_{2} \mathrm{~S}\right.$ in biogas) and synthetic waste gas matrix $\left(\mathrm{H}_{2} \mathrm{~S}\right.$ in air), using triphasic gas/liquid/solid process at room temperature and atmospheric pressure. As stated earlier and shown in Fig. 8, both $\mathrm{CH}_{4}$ and $\mathrm{CO}_{2}$ concentration levels were rather stable throughout the experiment, which was very positive for the study.

\section{Conclusions}

In this study, AC was found to be the most reactive for $\mathrm{H}_{2} \mathrm{~S}$ removal from the gas phase, followed by CCW-D, CCW-S and pure commercial calcite. Physisorption was predominant when using AC while acid-basic reaction and catalytic oxidation were predominant with calcium carbonate-based sorbents. Consequently, AC slowly lost its performance while the calcium carbonate-based wastes kept constantly their reactivity (by the catalytic oxidation). In the biogas matrix, only AC and CCW-D were investigated. CCW-D quickly lost its reactivity because no oxidation reaction took place, which was due to the absence of oxygen in the biogas matrix used. AC showed again its high performance for the physisorption of $\mathrm{H}_{2} \mathrm{~S}$. But its reactivity was lower in the biogas matrix than in the air matrix (at the same sorbent weight used of $0.5 \mathrm{~g}$ ), which could be explained by the competitive adsorption of $\mathrm{CH}_{4}$ and $\mathrm{CO}_{2}$ present in the biogas matrix.

The reactivity of different mixtures of AC and CCW-D were also investigated in the biogas matrix. At the same sorbent load of $2.5 \mathrm{~g}$ with at least $50 \mathrm{wt} \%$ of $\mathrm{AC}$, a synergy effect of the mixture was observed for the removal of $\mathrm{H}_{2} \mathrm{~S}$, compared to the individual sorbent. This beneficial effect was explained by the combination of the high basicity of CCW-D (by the dissolution of calcium carbonate) and the high specific surface area of AC, available for the fixation of the sulfide species. Therefore, calcium carbonate waste can be used as co-sorbent with $\mathrm{AC}$ in the triphasic process for the removal of $\mathrm{H}_{2} \mathrm{~S}$ from the gas phase. This opens new perspective for the valorization of this kind of solid wastes, in particularly for the purification of biogas.

\section{Acknowledgements}

The first author acknowledges the support from the School of Civil Engineering, University College Dublin, tuition scholarship support from Student Universal Support Ireland (SUSI) and Universite' de Toulouse, Mines Albi, CNRS UMR 5302, Centre RAPSODEE, Campus Jarlard, Albi, F-81013 cedex 09, France. The author gratefully acknowledges colleagues and technical staff at RAPSODE Center for technical help.

\section{References}

[1] H. Böni, R. Hischier, M. Lehmann, R. Zah, M., Gauch, P. Wager, Life cycle assessment of energy products: environmental impact assessment of biofuels - executive summary (only translated portion), (2007).

[2] F. Van Foreest, Perspectives for Biogas in Europe, Oxford Institute for Energy Studies, 2012. http://www.oxfordenergy.org/wpcms/wp-content/uploads/ 2012/12/NG-70.pdf.

[3] G. Busch, J. Großmann, M. Sieber, M. Burkhardt, A new and sound technology for biogas from solid waste and biomass, Water Air Soil Pollut. Focus 9 (2009) 89-97, doi:http://dx.doi.org/10.1007/s11267-008-9195-5.

[4] C.L. Hansen, D.Y. Cheong, Chapter 23-Agricultural waste management in food processing, Handb. Farm, Dairy Food Mach Eng, (2013), pp. 619-666, doi: http://dx.doi.org/10.1016/B978-0-12-385881-8.00023-9.

[5] Swedish Gas Technology Centre, Basic data of biogas, Phys. Radiol. (2012) 719739 ISBN 978-91-85207-7.
[6] S.E. Hosseini, M.A. Wahid, Development of biogas combustion in combined heat and power generation, Renew. Sustain. Energy Rev. 40 (2014) 868-875, doi:http://dx.doi.org/10.1016/j.rser.2014.07.204.

[7] C.F. Cullis, M.M. Hirschler, Atmospheric sulphur: natural and man-made sources, Atmos. Environ. 14 (1980) 1263-1278, doi:http://dx.doi.org/10.1016/ 0004-6981(80)90228-0.

[8] O. Badr, S.D. Probert, Atmospheric sulphur: trends, sources, sinks and environmental impacts, Appl. Energy 47 (1994) 1-67, doi:http://dx.doi.org/ 10.1016/0306-2619(94)90030-2.

[9] J. Wang, Y. Zhang, L. Han, L. Chang, W. Bao, Simultaneous removal of hydrogen sulfide and mercury from simulated syngas by iron-based sorbents, Fuel 103 (2013) 73-79, doi:http://dx.doi.org/10.1016/j.fuel.2011.10.056.

[10] W.M. Budzianowski, A review of potential innovations for production, conditioning and utilization of biogas with multiple-criteria assessment, Renew. Sustain. Energy Rev. 54 (2016) 1148-1171, doi:http://dx.doi.org/ 10.1016/j.rser.2015.10.054

[11] J.I. Huertas, N. Giraldo, S. Izquierdo, Removal of $\mathrm{H} 2 \mathrm{~S}$ and $\mathrm{CO}_{2}$ from biogas by amine absorption, Mass Transf. Chem. Eng. Process. 307 (2011), doi:http://dx. doi.org/10.5772/20039.

[12] E. Ryckebosch, M. Drouillon, H. Vervaeren, Techniques for transformation of biogas to biomethane, Biomass Bioenergy 35 (2011) 1633-1645, doi:http://dx. doi.org/10.1016/j.biombioe.2011.02.033.

[13] F. Pouliquen, C. Blanc, E. Arretz, I. Labat, J. Tournier-Lasserve, A. Ladousse, J. Nougayrede, G. Savin, R. Ivaldi, M. Nicolas, J. Fialaire, R. Millischer, C. Azema, L. Espagno, H. Hemmer, J. Perrot, Hydrogen sulfide, Ullmann's Encycl. Ind. Chem., Wiley-VCH Verlag GmbH \& Co. KGaA, 2000, doi:http://dx.doi.org/10.1002/ 14356007.a13_467.

[14] N. Abatzoglou, S. Boivin, A review of biogas purification processes, Biofuels Bioprod. Biorefin. 3 (2009) 42-71, doi:http://dx.doi.org/10.1002/bbb.117.

[15] X. Zhang, G. Dou, Z. Wang, L. Li, Y. Wang, H. Wang, Z. Hao, Selective catalytic oxidation of H2S over iron oxide supported on alumina-intercalated Laponite clay catalysts, J. Hazard. Mater. 260 (2013) 104-111, doi:http://dx.doi.org/ 10.1016/j.jhazmat.2013.05.008.

[16] I. Omri, H. Bouallagui, F. Aouidi, J.J. Godon, M. Hamdi, $\mathrm{H}_{2} \mathrm{~S}$ gas biological removal efficiency and bacterial community diversity in biofilter treating wastewater odor, Bioresour. Technol. 102 (2011) 10202-10209, doi:http://dx. doi.org/10.1016/j.biortech.2011.05.094.

[17] R. Lebrero, A.C. Gondim, R. Perez, P.A. Garcia-Encina, R. Munoz, Comparative assessment of a biofilter, a biotrickling filter and a hollow fiber membrane bioreactor for odor treatment in wastewater treatment plants, Water Res. 49 (2014) 339-350, doi:http://dx.doi.org/10.1016/j.watres.2013.09.055.

[18] S. Kang, Y. Seo, W. Jang, Y. Seo, C. Fossil, Gas Hydrate Process for Recovery of CO, (2009) . http://citeseerx.ist.psu.edu/viewdoc/download? doi=10.1.1.628.8870\&rep=rep1\&type=pdf.

[19] X. Wang, G. Chen, L. Yang, L. Zhang, Study on the recovery of hydrogen from refinery (hydrogen + methane) gas mixtures using hydrate technology, Sci. China Ser. B Chem. 51 (2008) 171-178, doi:http://dx.doi.org/10.1007/s11426007-0131-8.

[20] Q. Sun, H. Li, J. Yan, L. Liu, Z. Yu, X. Yu, Selection of appropriate biogas upgrading technology-a review of biogas cleaning, upgrading and utilisation, Renew. Sustain. Energy Rev. 51 (2015) 521-532, doi:http://dx.doi.org/10.1016/j. rser.2015.06.029.

[21] H. Tajima, A. Yamasaki, F. Kiyono, Energy consumption estimation for greenhouse gas separation processes by clathrate hydrate formation, Energy 29 (2004) 1713-1729, doi:http://dx.doi.org/10.1016/j. energy.2004.03.003.

[22] B. Castellani, F. Rossi, M. Filipponi, A. Nicolini, Hydrate-based removal of carbon dioxide and hydrogen sulphide from biogas mixtures: experimental investigation and energy evaluations, Biomass Bioenergy 70 (2014) 330-338, doi:http://dx.doi.org/10.1016/j.biombioe.2014.08.026.

[23] R. Muñoz, L. Meier, I. Diaz, D. Jeison, A review on the state-of-the-art of physical/chemical and biological technologies for biogas upgrading, Rev. Environ. Sci. Biotechnol. 14 (2015) 727-759, doi:http://dx.doi.org/10.1007/ s11157-015-9379-1.

[24] F.J. Gutiérrez Ortiz, P.G. Aguilera, P. Ollero, Biogas desulfurization by adsorption on thermally treated sewage-sludge, Sep. Purif. Technol. 123 (2014) 200-213, doi:http://dx.doi.org/10.1016/j.seppur.2013.12.025.

[25] M. Mora, M. Fernández, J.M. Gómez, D. Cantero, J. Lafuente, X. Gamisans, D. Gabriel, Kinetic and stoichiometric characterization of anoxic sulfide oxidation by SO-NR mixed cultures from anoxic biotrickling filters, Appl. Microbiol. Biotechnol. 99 (2014) 77-87, doi:http://dx.doi.org/10.1007/s00253-014-56885.

[26] A.M. Montebello, Aerobic Biotrickling Filtration or Andrea Monzón Montebello, Universitat Autonoma de Barcelona, Bellatera, 2013.

[27] J.-H. Yoon, H. Lee, Clathrate phase equilibria for the water-phenol-carbon dioxide system, AIChE J. 43 (1997) 1884-1893, doi:http://dx.doi.org/10.1002/ aic.690430723.

[28] H. Pham Xuan, D. Pham Minh, M. Galera Martı'nezz, A. Nzihou, P. Sharrock, Valorization of calcium carbonate-based solid wastes for the treatment of hydrogen sulfide from the gas phase, Ind. Eng. Chem. Res. 54 (2015) 49154922, doi:http://dx.doi.org/10.1021/acs.iecr.5b00764.

[29] N. Yoshizawa, K. Maruyama, Y. Yamada, M. Zielinska-Blajet, XRD. evaluation of $\mathrm{CO}_{2}$ activation process of coal- and coconut shell-based carbons, Fuel 79 (2000) 1461-1466, doi:http://dx.doi.org/10.1016/S0016-2361(00)00011-9.

[30] A. Guinier, X-Ray Diffraction In Crystals, Imperfect Crystals, and Amorphous Bodies, Dover Publications Inc, New York, 1994. 
[31] C. Winter, J.N. Caetano, A.B.C. Araújo, A.R. Chaves, I.C. Ostroski, B.G. Vaz, C.N. Pérez, C.G. Alonso, Activated carbons for chalcone production: ClaisenSchmidt condensation reaction, Chem. Eng. J. 303 (2016) 604-610, doi:http:// dx.doi.org/10.1016/j.cej.2016.06.058.

[32] M. Galera Martinez, Valorisation des résidus carbonatés industriels pour le traitement de sulfure d'hydrogène dans les effluents gazeux, Université de Toulouse, 2015.

[33] Sodium Carbonate Productions, (n.d.). http://www.societechimiquedefrance. fr/extras/Donnees/mine/naco/texnaco.htm (Accessed 1 August 2016).

[34] G. Steinhauser, Cleaner production in the Solvay Process: general strategies and recent developments, J. Clean. Prod. 16 (2008) 833-841, doi:http://dx.doi. org/10.1016/j.jclepro.2007.04.005

[35] T. Kasikowski, R. Buczkowski, B. Dejewska, K. Peszyńska-Białczyk, E. Lemanowska, B. Igliński, Utilization of distiller waste from ammonia-soda processing, J. Clean. Prod. 12 (2004) 759-769, doi:http://dx.doi.org/10.1016/ S0959-6526(03)00120-3.

[36] C. Gao, Y. Dong, H. Zhang, J. Zhang, Utilization of distiller waste and residua mother liquor to prepare precipitated calcium carbonate, J. Clean. Prod. 15 (2007) 1419-1425, doi:http://dx.doi.org/10.1016/j.jclepro.2006.06.024.

[37] S. Stita, M. Galera Martínez, H. Pham Xuan, D. Pham Minh, A. Nzihou, P. Sharrock, Metal-doped apatitic calcium phosphates: preparation, characterization, and reactivity in the removal of hydrogen sulfide from gas phase, Compos. Interfaces 22 (2015) 503-515, doi:http://dx.doi.org/10.1080/ 09276440.2015 .1049096

[38] D. Pham Minh, N.D. Tran, A. Nzihou, P. Sharrock, Calcium phosphate based materials starting from calcium carbonate and orthophosphoric acid for the removal of lead(II) from an aqueous solution, Chem. Eng. J. 243 (2014) 280 288, doi:http://dx.doi.org/10.1016/j.cej.2014.01.032.
[39] J. Lasocki, K. Kołodziejczyk, A. Matuszewska, Laboratory-scale investigation of biogas treatment by removal of hydrogen sulfide and Carbon Dioxide, Pol. J. Environ. Stud. 24 (2015) 1427-1434, doi:http://dx.doi.org/10.15244/pjoes/ 35283.

[40] A. Ansari, A. Bagreev, T.J. Bandosz, Effect of adsorbent composition on H2S removal on sewage sludge-based materials enriched with carbonaceous phase, Carbon N. Y. 43 (2005) 1039-1048, doi:http://dx.doi.org/10.1016/j. carbon.2004.11.042.

[41] W. Yuan, TJ. Bandosz, Removal of hydrogen sulfide from biogas on sludgederived adsorbents, Fuel 86 (2007) 2736-2746, doi:http://dx.doi.org/10.1016/j. fuel.2007.03.012

[42] Y. Xiao, S. Wang, D. Wu, Q. Yuan, Experimental and simulation study of hydrogen sulfide adsorption on impregnated activated carbon under

anaerobic conditions, J. Hazard. Mater. 153 (2008) 1193-1200, doi:http://dx. doi.org/10.1016/j.jhazmat.2007.09.081.

[43] M. Persson, O. Jonsson, A. Wellinger, Biogas upgrading to vehicle fuel standards and grid injection, IEA Bioenergy (2007) 1-32.

[44] L. Bailón Allegue, J. Hinge, Biogas and bio-syngas upgrading, DTU Rep. (2012) 1-97.

[45] L. Bailón Allegue, J. Hinge, Biogas Upgrading Evaluation of Methods for H, ( 2014), pp. 1-31.

[46] F. Bauer, C. Hulteberg, T. Persson, D. Tamm, Biogas Upgrading -Review of Commercial Technologies, Swedish Gas Technol. Centre, SGC, 2013, pp. 82 SGC Rapport 2013:270.

[47] A. Petersson, A. Wellinger, Biogas upgrading technologies-developments and innovations, IEA Bioenergy (2009) 20. http://typo3.dena.de/fileadmin/biogas/ Downloads/Studien/IEA-BiogasUpgradingTechnologies2009.pdf. 